\title{
Effects of solar radiation on regeneration patterns in a Nothofagus dombeyi (Mirb.) Oerst. old-growth forest in Chile's central-southern Andes
}

\author{
Efectos de la radiación solar sobre los patrones de la regeneración, en un bosque \\ sobremaduro de Nothofagus dombeyi (Mirb.) Oerst. localizado en el centro-sur de los \\ Andes, Chile
}

\author{
Pamela Encina ${ }^{1 *}$, Rolando Rodríguez ${ }^{1}$, Burkhard Müller-Using ${ }^{1}$, Peter Annighöfer ${ }^{2}$, Darcy Ríos \\ Leal $^{1}$, Katia Sáez-Carrillo ${ }^{3}$ \& Manuel Sánchez-Olate ${ }^{1}$ \\ ${ }^{1}$ Department of Silviculture, University of Concepción, Concepción, Chile. \\ ${ }^{2}$ Department of Silviculture and Forest Ecology of the Temperate Zones, University of Göttingen, Göttingen, Baja Sajonia, \\ 37077, Germany. \\ ${ }^{3}$ Department of Statistics, University of Concepción, Concepción, Chile. \\ *pamelaencina@udec.cl
}

\begin{abstract}
Nothofagus species behave like early successional species that recolonize open sites after of regular and large-scale disturbances. This study analyzed the effects of light regimes on patterns of advanced regeneration dynamics, growth in diameter and height of Nothofagus dombeyi (Mirb.) Oerst. (Density of 240 trees ha ${ }^{-1}$, basal area of $56.7 \mathrm{~m}^{2} \mathrm{ha}^{-1}$ ). Systematic sampling every $50 \mathrm{~m}$ in three stands $(7.5 \mathrm{ha}$ ) was used. At each point and with the same center, two concentric circular plots were established, $9.0 \mathrm{~m}$ and $1.8 \mathrm{~m}$ radius. For estimate solar radiation transmissivity in plots, a solariscope hemispheric photographic camera was used. Diameters at breast height and basal areas (BA), heights (H) were measured and then counted and measured $N$. dombeyi seedlings and saplings. 13 saplings of advanced regeneration were harvested from all gaps to obtain age (E), total height (TH), absolute radial growth (ARG), and absolute height growth (AHG). As results, solar radiation varied between 3 and $40 \%$. ARG varied between 1.20 and $2.22 \mathrm{~mm} \mathrm{yr}^{-1}$ and AHG between 0.15 and 0.43 $\mathrm{m} \mathrm{yr}^{-1}$. We found correlation for ARG and AHG with direct and global solar radiation transmissivity, but not with diffuse solar radiation transmissivity. The plant age and transmittance of direct and global solar radiation explains the increases in diameter and height. However, in our study stated that in the Andean region of south-central Chile, N. dombeyi stands is affected by small-scale disturbances. Therefore, transmissivity radiation solar inside the forest, explaining natural regeneration patterns and growth of $N$. dombeyi.
\end{abstract}

KEYwORDS: Advanced regeneration, disturbance, solar radiation transmissivity.

\section{RESUMEN}

Las especies de Nothofagus se comportan como especies sucesionales tempranas que recolonizan sitios abiertos después de disturbios regulares y de gran escala. Este estudio analizó los efectos de los regímenes de luz, en los patrones de dinámica de regeneración avanzada, crecimiento en diámetro y altura de Nothofagus dombeyi (Mirb.) Oerst. (Densidad de 240 árboles ha-1 área basal de $56,7 \mathrm{~m}^{2}$ ha-1). Se utilizó un muestreo sistemático cada $50 \mathrm{~m}$ en tres rodales $(7,5 \mathrm{ha})$. En cada punto y con el mismo centro se establecieron dos parcelas circulares, 9,0 m y 1,8 m de radio. Se midió la transmisividad de la radiación solar con una cámara fotográfica hemisférica solariscope. Se midieron los diámetros a la altura del pecho, áreas basales (BA), alturas (H) y se contaron las plántulas y plantas de $N$. dombeyi. En los claros se cosecharon 13 plantas de la regeneración avanzada, para obtener la edad (E), la altura total $(\mathrm{TH})$, el crecimiento radial absoluto (ARG) y el crecimiento absoluto en altura (AHG). La radiación solar varió entre 3 y 40\%. ARG varió entre 1,20 y 2,22 mm año ${ }^{-1}$ y AHG entre 0,15 y $0,43 \mathrm{~m}_{\text {año }}{ }^{-1}$. Se encontró correlación para ARG y AHG con transmisividad de radiación solar directa y global, pero no con transmisividad de radiación solar difusa. La edad de la planta y la transmitancia de la radiación solar directa y global explicaron los aumentos en diámetro y altura. Sin embargo, en nuestro estudio se indicó que en la región andina del centro-sur de Chile, los rodales de $N$. dombeyi se ven afectados por disturbios a pequeña escala. Por tanto, la radiación de transmisividad solar dentro del bosque explica los patrones de regeneración natural y el crecimiento de $N$. dombeyi. 


\section{INTRODUCTION}

Silviculturalist have recognised the importance of natural disturbances in the development and maintenance of forest structures, functions and community dynamics (Attiwill 1994). Small-scale disturbances eliminate original vegetation, leaving open spaces in stands which represent canopy gaps (Parhizkar et al. 2011) and facilitate resources such as light, nutrients and water (Valladares \& Niinemets, 2008). The temporary increase in light availability below the first canopy layer (Canham et al. 1990) varies at stand level more than for any other plant resource (Martens et al. 2000). The most important factors that explain this spatial variation in understory light levels are canopy shape, size, and distribution of neighbouring trees and local sky brightness distribution (Canham et al. 1999). Light is highly variable in time and space (Valladares \& Guzmán 2006), as conditions change drastically over time and canopy gaps, essential for plant growth and survival, form (Canham et al. 1990; Hu \& Zhu 2008; Kneeshaw \& Bergeron 1998; Mountford et al. 2006). Therefore, light is a key factor affecting dynamics and succession of plant communities and the spectrum of species in forest ecosystems.

In central-southern Chile, Nothofagus species behave like early successional species that recolonize open sites after prior vegetation removal due to regular and large-scale disturbances such as landslides, material deposits from massive flooding or trees knocked down by strong winds (Veblen et al. 1996a). Without subsequent disturbances, later successional species tend to settle under the canopy, replacing shade-intolerant species such as $N$. dombeyi (Mirb.) Oerst., which is key to regeneration after largescale disturbances (Veblen et al. 1996b). Every old-growth forest has certain characteristics, species, processes and interactions that rarely -or not at all- appearing younger forests. Old-growth forests belong to the natural diversity of life on Earth. It depends on our effort to conserve biological diversity from the scale of genes to ecosystems; it is important that we conserve old-growth in its natural spatial pattern, i.e., large, continuous expanses (Lapin 2005).

Nothofagus species have limited opportunities to recruit even in large canopy gaps $\left(>1,000 \mathrm{~m}^{2}\right)$ due to the release of advance regeneration of shade-tolerant trees and the vigorous proliferation of Chusquea spp. bamboos (Veblen et al. 1996a). Tree-fall gaps are larger and logs more abundant in old-growth Nothofagus spp. dominated stands (Schlegel \& Donoso 2008), and these conditions can help Nothofagus spp. tree recruitment. $N$. dombeyi and N. alpina (Poepp. \& Endl.) Oerst. can reach over $2 \mathrm{~m}$ in diameter at breast height (dbh) and above $50 \mathrm{~m}$ in height; both species can grow 10 to $30 \mathrm{~m}$ above the main canopy (Donoso \& Lusk 2007; González et al. 2015). However, old-growth Nothofagus stands growing in the Andean region of south-central Chile are more affected by small- scale disturbances from Chusquea culeou (Desvaux.) bamboo thickets which suppress the regeneration of tree species and develop after canopy gaps formed. Depending on the abundance of $C$. culeou thickets, a biphasic pattern of positive feedback on the dynamics of regeneration of these forests has been suggested. In it, the first regeneration phase of $C$. culeou can give rise to a second phase of $N$. dombeyi regeneration (Lusk 2001). Winds and snow storms also remove overstory-trees individually or in smaller groups, resulting in small to medium-size canopy gaps that create a favourable environment for more shade-intolerant species. These species maximise their initial growth under higher light conditions, when is absent an aggressive colonizers C. culeou tickets since inhibit regeneration of tree species (Lusk 2001; Lusk \& Del Pozo 2002). But can grow under different light regimes after episodes of bamboo dieback that provide the main opportunities for reestablishment of tall forest (Lusk 2001). Therefore, management of the stand light regime through silvicultural techniques is required to ensure better regeneration of this species (Sola et al. 2016). In our study, $N$. dombeyi in an old-growth forest stand could reach more than $2 \mathrm{~m}$ in dbh and above $50 \mathrm{~m}$ in height. Treefalls of this size can create gaps larger than $700 \mathrm{~m}^{2}$. Canopy gaps formation has been largely recognised as an important process with indifferent forest ecosystems. However, studies on temperate forests of the southern hemisphere are still lacking compared to tropical forests and northern hemisphere temperate forests (González et al. 2015).

We hypothesise that the regeneration is the response to small-scale disturbance, therefore the high spatial variability of all solar radiation transmissivity components inside the forest varies due to the different degrees of canopy openings, which alter light regimes in pure old-growth $N$. dombeyi stands, explaining natural regeneration patterns and growth. Thus, the study objectives are to analyse light regimes in patterns of regeneration dynamics and the effect these light regimes have on diameter and height growth of plants that compose stands of advanced regeneration.

\section{METHODS}

STUDY AREA

The study took place in three $N$. dombeyi old-growth forest stands near Yungay city, Biobío Region in central Chile (Fig. 1). All stands belong to $N$. dombeyi and Saxegothea conspicua Lindl. bioclimatic area called Andean Mediterranean temperate evergreen forests (Luebert \& Pliskoff 2006). The stands are characterised by evergreen forest arboreal layers dominated by $N$. dombeyi, S. conspicua, Podocarpus nubigena Lindl., Laureliopsis philippiana (Looser) Schodde, and occasionally Weinmannia trichosperma Cav. species in the intermediate layers. However, in a state of old-growth, light conditions below the first canopy layer do 
often inhibit development of intermediate arboreal strata. The most characteristic geomorphological position of such a forest is in western mid-slopes of the Andes Mountains (Luebert \& Pliskoff 2006). The climate is Mediterranean, with rainfall concentrated during winter and a dry summer lasting three to four months. Study area altitudes (600-1,500 $\mathrm{m}$ a.s.1.) correspond to an area with temperate Mediterranean climate as classified by Emberger (Del Pozo \& Del Canto 1999). Average annual rainfall exceeds $1,400 \mathrm{~mm}$, and ice and snowfall can cause disturbances in the native forest, while growing season lasts around three months due to low winter temperatures (Del Pozo \& Del Canto 1999).

Soils originate from volcanic ash, most likely post glacial, resting on a non-related substrate comprising fluvial or glacio-fluvial materials that remain detected due to the depth at which they occur (Kühne et al. 2005). Soil is deep and medium-textured, generally silty loam within the first meter and silty clay loam at depths of $165 \mathrm{~cm}$ or more (Kühne et al. 2005).

\section{SEEDLING AND PLANT DENSITY MEASUREMENTS}

Field work was carried out in 2015 during Chile's growing season from January to February. To measure density of saplings (lignified) and seedlings (non-lignified), systematic sampling was carried out in three old-growth $N$. dombeyi stands with a total area of $7.5 \mathrm{ha}$, a 240 trees ha ${ }^{-1}$ density, a basal area of $56.7 \mathrm{~m}^{2} \mathrm{ha}^{-1}$ and 13 gaps of forest with an area between 45 and $300 \mathrm{~m}^{2}$. The starting position for the systematic grid was determined randomly. With this information and a map of the study site, lines were drawn with a distance of $50 \mathrm{~m}$ in a parallel and perpendicular direction, giving rise to a network of 64 points for the three stands; at each point, two concentric circular plots with an only center of radius $9.0 \mathrm{~m}$ (large plot) and $1.8 \mathrm{~m}$ (regeneration plot) were established (Fig. 2). Within each large plot, adult tree diameter at breast height (dbh) was measured with a caliper in order to derive diameter distributions, basal areas (BA), and analyse their relationship with the occurring regeneration of $N$. dombeyi. In the regeneration plots, the saplings were height measured and counted along with all germinated and non-lignified seedlings of $N$. dombeyi.

Tree seedlings and saplings of $N$. dombeyi were counted and classified as: germinant and non-lignified $<0.05 \mathrm{~m}$, and lignified $>0.051,0.051<0.5,0.5<1,1<1.5,1.5<2$, and $\geq 2 \mathrm{~m}$ of height. Furthermore in 13 open canopy plots, it was harvested one species of the tallest, between $3.0 \mathrm{~m}$ to $5.0 \mathrm{~m}$ height, one per each plots of forest, to determine ARG, and a stem analysis was used. In each species a first cut was made to ground level and every $1.0 \mathrm{~m}$ until apex. Each disk was divided in four quadrants, where register the distance from the medulla until to each ring, considering the first distance in the ring the closest to the medulla. The average of the four quadrants, was considered as the absolute radial growth ARG stem analysis measurements were performed using a standing digital meter with an accuracy of $0.01 \mathrm{~mm}$, for each distance of the rings to medulla. Total plant height and increases thereof were also analyzed obtain absolute height growth (AHG.)

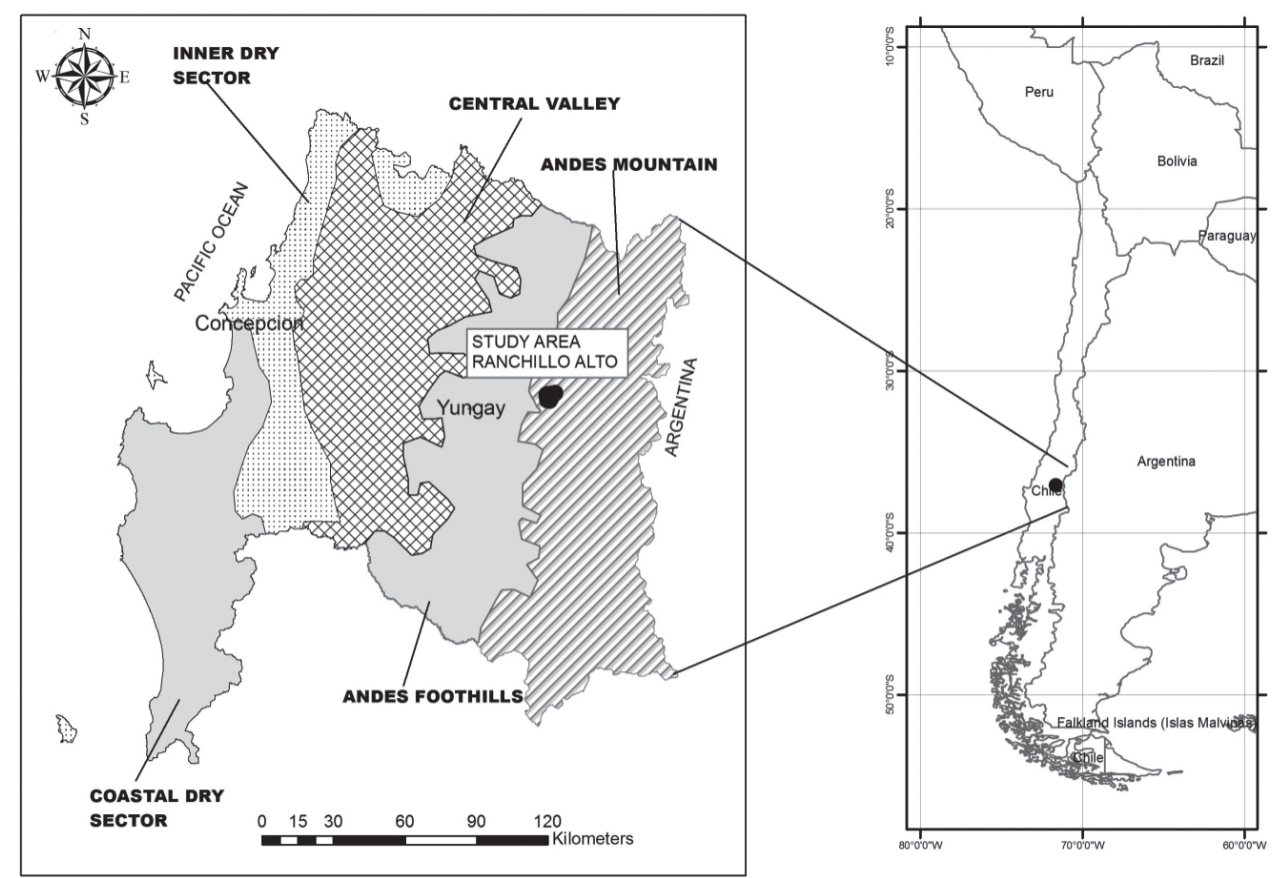

FiguRE 1. Orientation map of the study areain the Andes Mountains in the Biobío Region, Chile. / Mapa de orientación del área de estudio en la Cordillera de los Andes, Región del Biobío, Chile. 


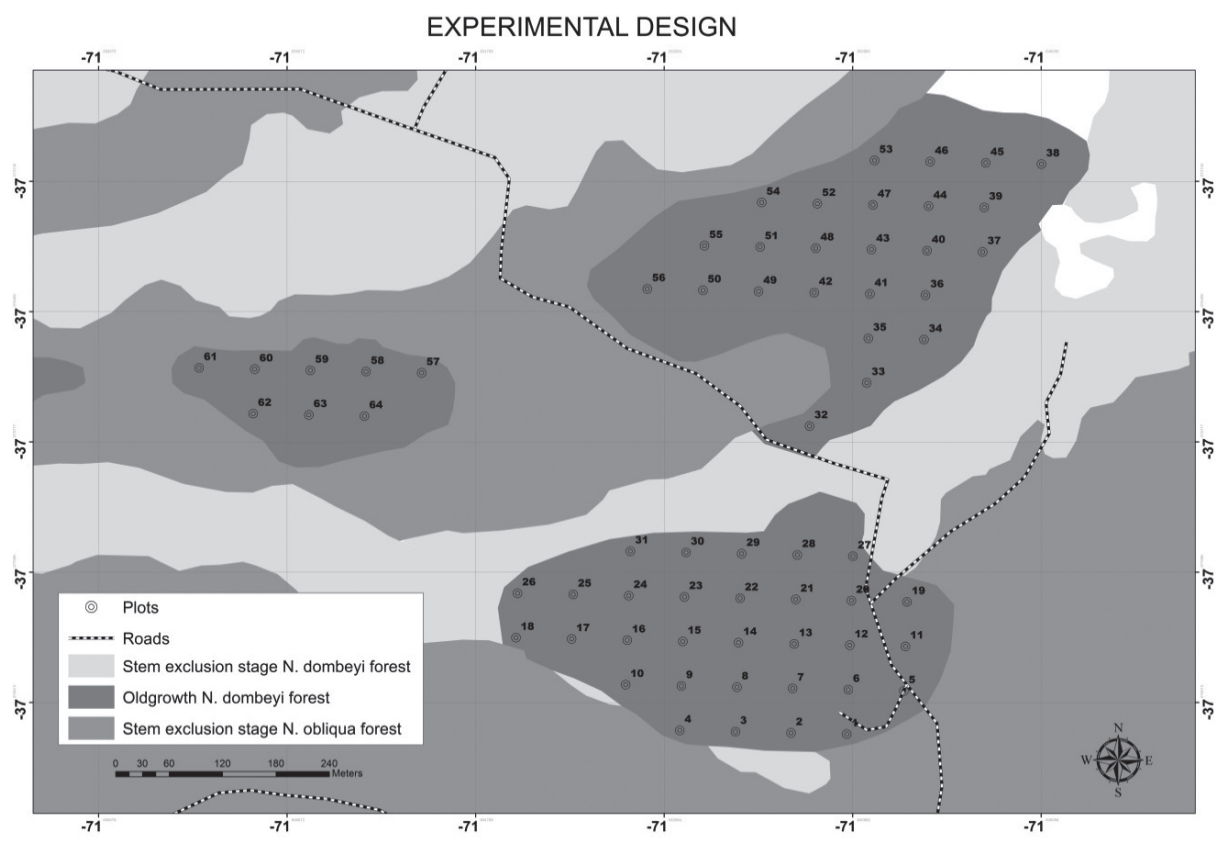

Figure 2. Map of the experimental design in the Andes Mountain in Chile's Biobío Region: numbers refer to plots; at each point, two concentric circular plots of radius of $9.0 \mathrm{~m}$ and $1.8 \mathrm{~m}$ (regeneration plot) were established, with a total of 64 points. / Mapa del diseño experimental en la Cordillera de los Andes en la Región del Biobío, Chile: los números se refieren a las parcelas. En cada punto se establecieron dos parcelas circulares concéntricas con un único centro de radio de 9,0 m y 1,8 m (parcela de regeneración), con un total de 64 puntos.

\section{LIGHT MEASUREMENTS}

Light conditions were measured in the center of each plot and solar radiation transmissivity was obtained for direct (Dir), diffuse (Dif) and global (GL) solar radiation by analysing hemispherical digital photos taken with a Solariscope camera (Behling SOL300, version 1.0). Photographs were taken during January 2015, two metres above ground when solar rays were vertical (between 11:00 and 15:00 h) (Vyncke 1969). Seven photographs were taken in each gap, resulting in 448 images as the best image per plot was visually selected, according to most accurate detection of canopy and sky.

\section{STATISTICAL ANALYSiS}

To analyse light regimes in patterns of regeneration it is necessary to explore using explanatory variables. By them, variables were correlated using Spearman's rank correlation coefficient to explore the relationship between varying densities of natural regeneration and solar radiation transmissivity, in $\mathrm{AHG}$ and $\mathrm{ARG}$ variable it was used Pearson rank correlation. To analyse the effect of light regimes have on diameter and height growth of plants, generalised linear regression models were used to evaluate natural regeneration density responses to Dir, Dif and GL variables. To detect significantes differences in variables, the Test Tukey, was used. Data and statistical analyses were performed using Statistica v.10 software, with significance values of $\mathrm{p}<0.05$.

\section{RESULTS}

SOLAR RADIATION TRANSMISSIVITY

Solar radiation transmissivity ranged from 3 to $39 \%$ with an average value of $13 \%$ (Fig. 3). Diffuse solar radiation transmissivity had an average value of $11 \%$, ranging between 3 and 28\%, while global radiation transmissivity reached an average of 12\%, ranging from 4 to $31 \%$ (Fig. 3 ). The ranges of variation in solar radiation transmission, whether direct, diffuse or global, were closely related to the different opening levels of the canopy (Table 1). Mean values of 8.6, 9.6 and 9.4\%, for Dir, Dif and GL solar radiation, respectively, represent a closed canopy, while mean values between 21.3 and 23.6\% for Dir, Dif or GL solar radiation represent centre gaps (Table 1). However, no significant differences were detected for the border and centre gap, as Dir, Dif or GL solar radiation showed significant differences between gap centre and border centre or closed canopy (Table 1).

INFLUENCE OF SOLAR RADIATION ON REGENERATION DENSITY Densities of natural regeneration for both seedlings and saplings varied widely within the forest between 0 and 14 plants $\mathrm{m}^{-2}$. Highest densities emerged around the centre gap, varying between 0 and 3 seedlings $\mathrm{m}^{-2}$ and 5 and 13 saplings $\mathrm{m}^{-2}$. In border gap densities, we recorded between 1 and 8 seedlings $\mathrm{m}^{-2}$ and 2 to 11 saplings $\mathrm{m}^{-2}$. However, under closed canopy, $43 \%$ of the plots did not present 
sapling while $57 \%$ of the plots presented sapling, density varied between 0 and 8 plants $\mathrm{m}^{-2}$ (Fig. 4). As advanced regeneration for saplings (saplings density) showed no normal distributions. Seedling density did not correlate

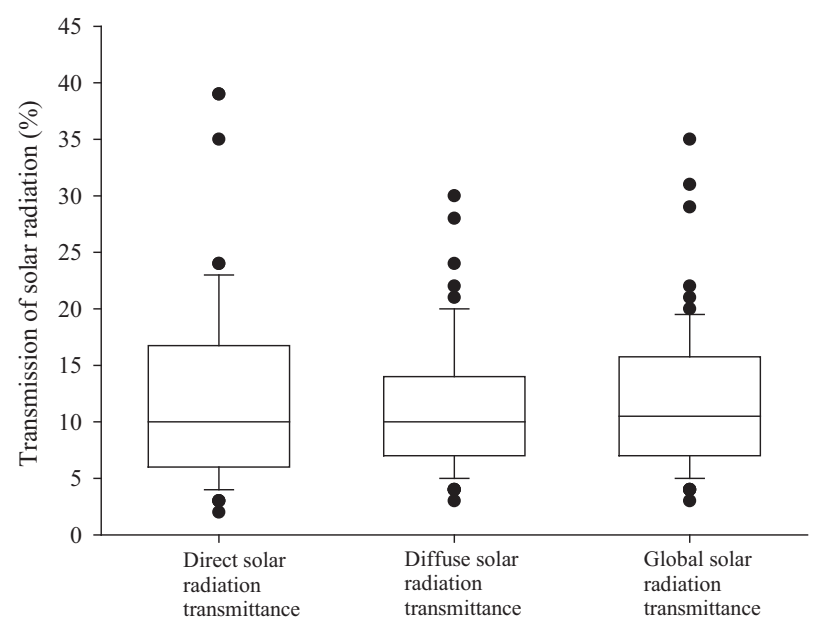

FIGURE 3. Solar transmittance at the 64 points of study: direct solar radiation, diffuse solar radiation, and global solar radiation in an old-growth forest of $N$. dombeyi in the Andean central-southern region of Chile. / Medición de la transmisividad solar en los 64 puntos de estudio: radiación solar directa, radiación solar difusa y radiación solar global en un bosque sobremaduro de $N$. dombeyi ubicado en la región andina centro-sur de Chile. with any solar radiation component. However, sapling density related highly significantly to diffuse radiation $(\mathrm{p}$ $<0.0001)$ and global solar radiation $(\mathrm{p}<0.0031)$ (Table 2$)$.

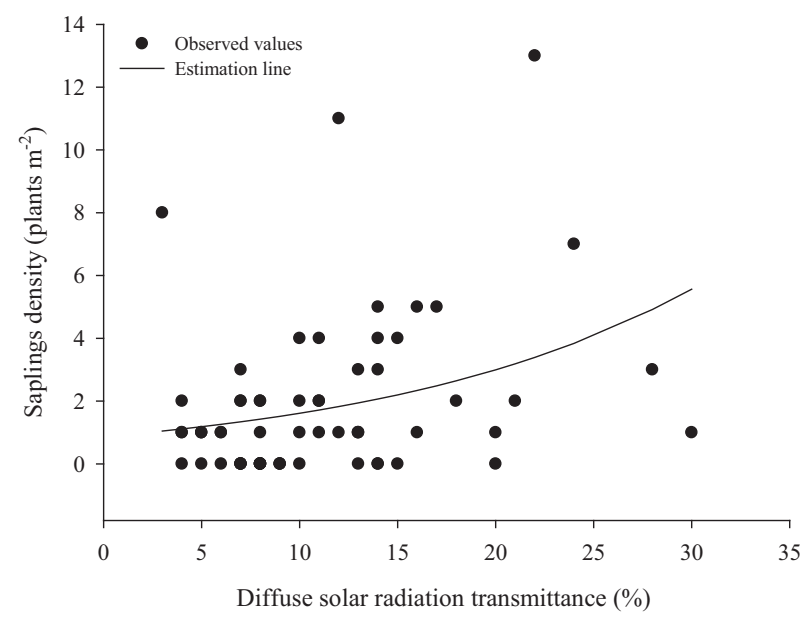

FIgURE 4. Poisson dispersion graphs howing the relationship between diffuse solar radiation transmittance and sapling density $\left(y=\exp ^{-0.1404+0.0619 x} ; \mathrm{R}^{2}=0.26 ; \mathrm{p}=0.0001\right)$ in an old-growth forest of $N$. dombeyi in Chile's central-southern Andean region. / Gráficos de dispersión de Poisson para la relación entre la transmisividad de la radiación solar difusa y la densidad de árboles jóvenes $(y=\exp$ $\left.0.1404+0.0619 x ; \mathrm{R}^{2}=0.26, \mathrm{p}=0.0001\right)$ en un bosque sobremaduro de $N$. dombeyi, ubicado en la región andina del sur de Chile.

TABLE 1. Mean values of solar radiation transmittance in an old-growth forest of $N$. dombeyi in the central-southern Andean region of Chile. / Valores medios de la transmisividad de la radiación solar de un bosque sobremaduro de $N$. dombeyi, ubicado en la región andina centro-sur de Chile.

\begin{tabular}{llll}
\hline \multicolumn{4}{l}{ Photo location In the Plot } \\
\hline VARiables & CENTRE GaP & Border GAP & Closed CANOPY \\
\hline Dir & $23.6^{\mathrm{a}} \pm 2.86$ & $10.8^{\mathrm{b}} \pm 3.08$ & $8.6^{\mathrm{b}} \pm 1.05$ \\
Dif & $21.3^{\mathrm{a}} \pm 1.72$ & $10.0^{\mathrm{b}} \pm 1.86$ & $9.6^{\mathrm{b}} \pm 0.64$ \\
GL & $22.6^{\mathrm{a}} \pm 2.17$ & $10.3^{\mathrm{b}} \pm 2.34$ & $9.4^{\mathrm{b}} \pm 0.80$ \\
\hline
\end{tabular}

Note: Dir is direct solar radiation transmittance; Dif is diffuse solar radiation transmittance and GL is global solar radiation transmittance. Rows with different letters indicate significant differences at $\mathrm{p}<0.05$ (Tukey Test). / Nota: Dir es la Transmisividad de la radiación solar directa; Dif es Transmisividad de la radiacion solar difusa y GL es la Transmisividad de la radiación solar global. Las filas con letras distintas indican diferencias significativas en $\mathrm{p}<0,05$ (Tukey Test).

TABLE 2. Spearman's rank correlation matrix for transmittance of solar radiation and natural regeneration density in an old-growth forest of $N$. dombeyi in the central-southern Andean region of Chile. / Matriz de correlación de Spearman's para la transmisividad de la radiación solar y la densidad de la regeneración natural de un bosque sobremaduro de $N$. dombeyi ubicado en la región andina centro-sur de Chile.

\begin{tabular}{llllll}
\hline VARIABLES & SED & SAD & DIR & Dif & GL \\
\hline SED & & $0.50^{*}$ & & & \\
SAD & $0.50^{*}$ & & & $0.36^{*}$ & $0.27^{*}$ \\
Dir & & & & $0.69^{*}$ & $0.95^{*}$ \\
Dif & & $0.36^{*}$ & $0.69^{*}$ & & $0.87^{*}$ \\
GL & & $0.27^{*}$ & $0.95^{*}$ & $0.87^{*}$ & \\
\hline
\end{tabular}

Note: SED is seedling density; SAD is saplings density; Dir is direct solar radiation transmittance; Dif is diffuse solar radiation transmittance and GL is global solar radiation transmittance. Symbol $(*)$ the correlation is statistically significant $(\mathrm{p} \leq 0.05)(\mathrm{n}=64)$. / Nota: SED es densidad de plántulas; SAD es la densidad de plantas en un rodal de un bosque sobremaduro; Dir es la Transmisividad de la radiacion solar directa; Dif es la Transmisividad de la radiacion solar difusa y GL es la Transmisividad de la radiacion solar global. Símbolo (*) la correlación es estadísticamente significativa $(\mathrm{p}<0,05)(\mathrm{n}=64)$. 
Density of advanced regeneration of $N$. dombeyi increased with rising diffuse radiation (Fig. 4). Notably, under 3\% in diffuse solar radiation transmittance regeneration does not occur and the maximum sapling regeneration density did not exceed $20 \%$ in diffuse solar radiation transmittance (Fig. 4). Considering the natural regeneration of seedlings and saplings, there was no correlation with the stand basal area (Table 2). Though the 0.051 to $0.5 \mathrm{~m}$ height classes in seedlings and saplings did not show a correlation with any solar radiation component, the remaining height classes showed at least one positive significant correlation (Table 3). Particularly sapling density regeneration showed a positive and significant correlation with diffuse and global solar radiation transmissivity (Table 3 ).

INFLUENCE OF SOLAR RADIATION ON RADIAL INCREASE AND PLANT HEIGHT

Advanced natural plant regeneration was observed on only 13 plots, which coincided with the borders or centres of canopy gaps in the stand. The average age of the tallest saplings (3-5 $\mathrm{m}$ in height) on the plot was 23 years $( \pm 7.1 \mathrm{SD})$ and $\mathrm{ARG}$ of plants varied between 1.20 and $2.22 \mathrm{~mm}_{\text {year }}{ }^{-1}$, with an average increment of $1.52 \mathrm{~mm}_{\text {year }}{ }^{-1}$. However, no correlation was observed between increasing radials and stand variables, such as basal area, total tree height and regeneration density. However, age presented a significant correlation $(\mathrm{p}<0.01)$ but negative with ARG $(\mathrm{r}=0.6)$ (Table 4). As global solar radiation transmissivity increased, $A R G$ also increased (Fig. 5 and Table 4). Lowest ARG was observed when solar radiation transmissivity was at 5\%, and highest when global solar radiation transmissivity values exceeded 35\% (Fig. 5). Absolute height growth values (AHG) increased from 0.15 and $0.43 \mathrm{~m}$ year $^{-1}$, with an average of $0.22 \mathrm{~m} \mathrm{year}^{-1}$ (Figs. 6 and 7). No correlation was observed between ARG and stands variables such as basal area or advanced regeneration species density. However, ARG and AHG presented a negative and significant correlation $(p<0.05)$ with age $(r=-0.71)$. In addition, it showed a significant and positive correlation $(\mathrm{p}<0.05)$ with the transmissivity of direct and global solar radiation $(\mathrm{r}=0.70$ for both) and a significant correlation ( $\mathrm{p}$ $<0.05)$ with the transmissivity of diffuse radiation $(\mathrm{r}=0.51$; $\mathrm{p}<0.05$ ) (Table 3). Two regression models were constructed for AHG. Both models for transmissivity of direct and global radiation are explained by the proportion of variance for both models $\left(\mathrm{R}^{2}=0.60 ; \mathrm{p}<0.01\right.$ and $\left.\mathrm{R}^{2}=0.70 ; \mathrm{p}<0.01\right)$ (Figs. 6 and 7). Height increase was influenced by the transmissivity of direct and global solar radiation.

TABLE 3. Spearman's rank correlation matrix for natural regeneration density according to height classes in relation to solar radiation transmittances in an old-growth forest of $N$. dombeyi in the central-southern Andean region of Chile. / Matriz de correlación de Spearman's para la densidad de la regeneración natural según las clases de altura en relación con la transmisividad de radiación solar en un bosque sobremaduro de $N$. dombeyi ubicado en la región andina centro-sur de Chile.

\begin{tabular}{cccc}
\hline Height classes $(\mathrm{m})$ & Dir & Dif & GL \\
\hline seedling & -0.19 & 0.04 & -0.11 \\
saplings & 0.14 & $0.36^{*}$ & $0.27^{*}$ \\
$0.051-0.5$ & -0.04 & 0.20 & 0.08 \\
$0.51-1.0$ & $0.28^{*}$ & $0.38^{*}$ & $0.37^{*}$ \\
$1.1-1.5$ & 0.17 & $0.36^{*}$ & $0.29^{*}$ \\
$1.51-2$ & 0.19 & $0.34^{*}$ & $0.29^{*}$ \\
$>2$ & 0.14 & $0.36^{*}$ & $0.28^{*}$ \\
\hline
\end{tabular}

Note: Dir is direct solar radiation transmittance; Dif is diffuse solar radiation transmittance and GL is global solar radiation transmittance. Symbol $(*)$ the correlation is statistically significant $(\mathrm{p} \leq 0.05)(\mathrm{n}=13)$. / Nota: Dir es la Transmisividad de la radiacion solar directa; Dif es la Transmisividad de la radiacion solar difusa y GL es la Transmisividad de la radiacion solar global. Símbolo (*) la correlación es estadísticamente significativa (p 0,05) ( $\mathrm{n}=13)$.

TABLE 4. Pearson rank correlation for absolute height growth (AHG) and absolute radial growth (ARG) and other measured variables in an old-growth forest of $N$. dombeyi in the central-southern Andean region of Chile. / Coeficiente de correlación de Pearson para el crecimiento de la altura absoluta (AHG) y el crecimiento radial absoluto (ARG) y otras variables medidas en un bosque sobremaduro de N.dombeyi ubicado en la región andina centro-sur de Chile.

\begin{tabular}{ccc}
\hline VARIABLES & AHG & ARG \\
\hline AHG & & $0.88^{*}$ \\
ARG & $0.88^{*}$ & \\
E & $-0.71^{*}$ & $-0.59^{*}$ \\
Dir & $0.70^{*}$ & 0.55 \\
GL & $0.70^{*}$ & $0.60^{*}$ \\
\hline
\end{tabular}

Note: $\mathrm{E}$ is the age of the highest plant in the plot, Dir is direct solar radiation transmittance and Gl is global solar radiation. Symbol (*) the correlation is statistically significant $(\mathrm{p} \leq 0.05)(\mathrm{n}=13)$. / Nota: E es la edad de la planta más alta en la parcela, Dir es la Transmisividad de la radiacion solar directa y GL es la Transmisividad de la radiacion solar global. Símbolo $\left.{ }^{*}\right)$ la correlación es estadísticamente significativa $(\mathrm{p} 0,05)(\mathrm{n}=13)$. 


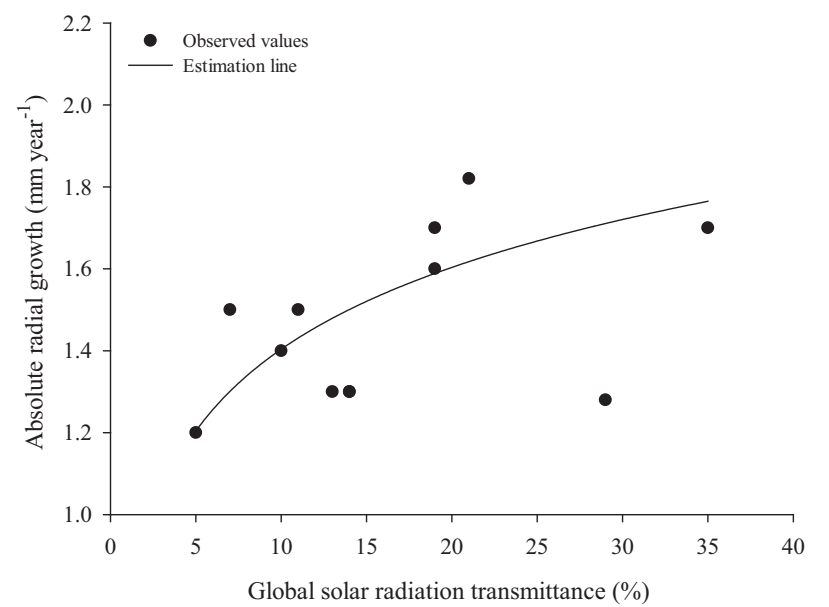

Figure 5. Scatter diagram for the relationship between global solar radiation transmittance and absolute radial growth (ARG $\left.=0.7398+0.6638 * \log 10(\mathrm{x}) ; \mathrm{R}^{2}=0.60 ; \mathrm{p}=0.031\right)$ in an oldgrowth forest of $N$. dombeyi in the central-southern Andean region of Chile. / Diagramas de dispersión para la relación entre la transmisividad de la radiación solar global y el crecimiento radial absoluto $\left(\mathrm{ARG}=0,7398+0,6638 * \log 10(\mathrm{x}), \mathrm{R}^{2}=0,60 ; \mathrm{p}=\right.$ 0,031 ) en un bosque sobremaduro de $N$. dombeyi en el centro-sur región andina de Chile.

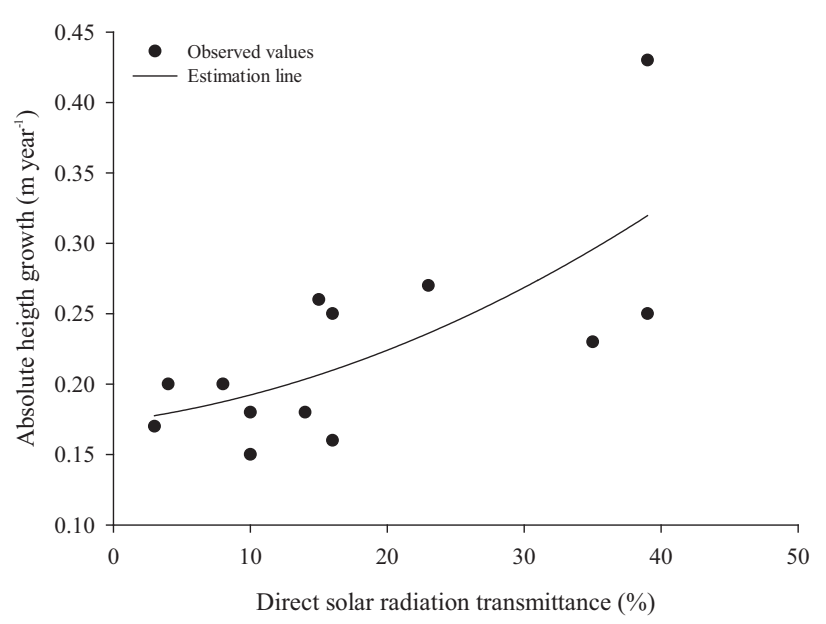

FIGURE 6. Scatter diagram showing the relationship between direct solar radiation transmittance $(\%)$ and absolute height growth $\left(\mathrm{AHG}=0.1733+0.0013 * \mathrm{x}+6.3677 \mathrm{e}^{-5} * \mathrm{x}^{2} ; \mathrm{R}^{2}=0.69\right.$, $\mathrm{p}=0.0081)$ in an old-growth forest of $N$. dombeyi in the centralsouthern Andean region of Chile. / Diagramas de dispersión para la relación entre la transmisividad directa de la radiación solar (\%) $\mathrm{y}$ el incremento absoluto de la altura $(\mathrm{AHG}=0,1733+0,0013 * \mathrm{x}$ $\left.+6,3677 \mathrm{e}^{-5 *} \mathrm{x}^{2} ; \mathrm{R}^{2}=0,69, \mathrm{p}=0,0081\right)$ en un bosque sobremaduro de $N$. dombeyi ubicado en la región centro-meridional andina de Chile.

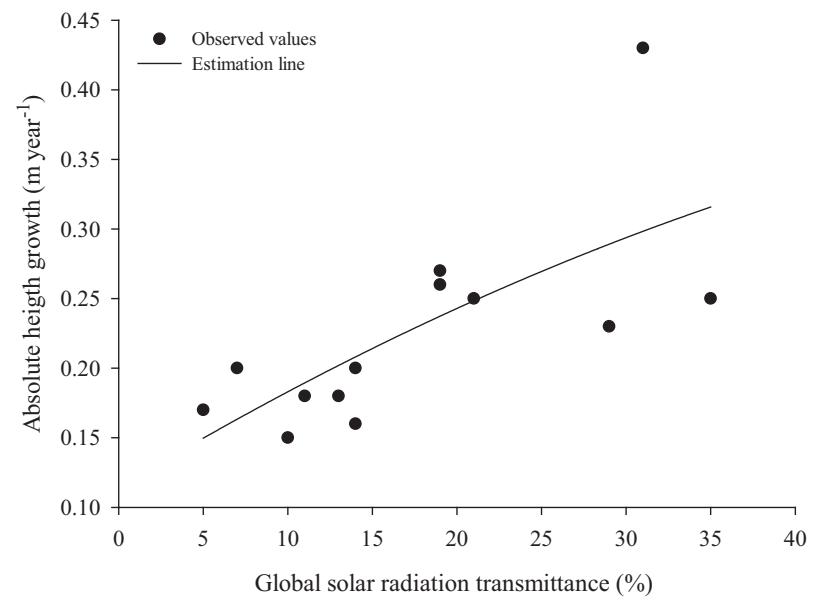

FIGURE 7. Scatter diagram for the relationship between global solar radiation transmittance $(\%)$ and absolute height growth $(\mathrm{AHG}=$ $\left.0.1141+0.00073 * \mathrm{x}-4.5354 \mathrm{e}^{-5} * \mathrm{x}^{2} ; \mathrm{R}^{2}=0.703 ; \mathrm{p}=0.0073\right)$ in an $N$. dombeyi old-growth forest in Chile's central-southern Andean region. / Diagramas de dispersión para la relación entre la transmisividad de la radiación solar global (\%) y el crecimiento de la altura absoluta $\left(\mathrm{AHG}=0,1141+0,00073 * \mathrm{x}-4,5354 \mathrm{e}^{-5} * \mathrm{x}^{2} ; \mathrm{R}^{2}\right.$ $=0,703 ; \mathrm{p}=0,0073)$ en un bosque sobremaduro de $N$. dombeyi que crece en la región centro-meridional andina de Chile.

\section{DISCUSSION}

SOLAR TRANSMISSIVITY MEASUREMENTS AND DIFFERENTIATION OF GLOBAL, DIRECT AND DIFFUSE RADIATION COMPONENTS

Both intensity and direction of solar radiation transmissivity in forests are constantly changing due to daily and yearly movements of celestial bodies and the Earth in relation to the sun's position and cloud cover (Baldocchi \& Collineau 1994). When tree canopies, shrubs or herbaceous strata at a particular site vary in size, shape and opacity, the transmissivity of solar radiation penetrating the canopy transforms, creating a wide variation of incoming light in the forest (Lieffers et al. 1999). In our stands showed high spatial variability for all transmissivity components of solar radiation inside forests (3 to 40\%, Fig. 3), likely due to different degrees of canopy coverage caused by small-scale disturbance. In this sense, patterns of spatial solar radiation transmissivity observed in the study area are consistent with changes occurring in forests, particularly the presence of different gaps, canopies surface characteristics, and gap size and location (Parker et al. 2002). This has been proven through models (Hardy et al. 2004) showing that spatial changes in solar radiation transmissivity are due to the highly variable nature of light and canopy geometry, particularly discontinuous canopies, as seems to be the case for $N$. dombeyi old-growth forest stands. It is necessary to consider that sunfleck spectra are similar to direct solar radiation transmissivity (Leuchner et al. 2012), which can be physiologically important since plants use this solar 
radiation in photosynthesis (Dengel et al. 2015). In this sense, stands under forest understory conditions, leaves are at intermediate induction states for most of the day and the ability to utilize sunflecks may therefore be strongly influenced by the ability of leaves to maintain relatively high states of induction during long periods of low light (Chazdon \& Pearcy 1986) and shade-tolerant species show that, particularly in low light, they are capable of efficient sunfleck utilization (Rijkers et al. 2000).

It is necessary to refer to the dominant solar environment of $N$. dombeyi old-growth forests, since it corresponds to the growth responses of temperate forests in a Mediterranean climate. It has been reported that this lighting can account for $15 \%$ of midday radiation coming through the canopy and $40 \%$ of the radiation below the shrub layer in deciduous leaf stands, representing between 14 and $41 \%$ of canopy transmittance for stands dominated by conifers (Canham et al. 1994); this also explains increases in diffuse light proportions under canopies (Dengel et al. 2015). Sunfleck spectra are similar to incident radiation (Leuchner et al. 2012) and could also function in areas with transiently higher temperatures, sometimes leading to physiological significance (Dengel et al.2015), as in the case of the present study area. It is important to note that the transmissivity of diffuse solar radiation enhances terrestrial vegetation photosynthesis (Dengel et al. 2015), while the transmissivity of direct solar radiation can cause photosynthesis saturation in the upper canopy and possibly photoinhibition (Long et al. 1994).

The area under study has beenaffected to varying intensity and duration by recurring snowstorms and wind (Mitchell 2013), forming large gaps with a high proportion of surviving trees, creating gaps mosaics (Mitchell 2013). Wide crowns of $N$. dombeyi retain snow until damage occurs under snow weight pressure, but with more intense storms, a larger number of trees break or are uprooted, which opens the canopies, resulting in gaps, as Mitchell (2013) reported. Therefore, high spatial variability in solar radiation transmissivity due to these disturbances can satisfactorily explain structural changes and regeneration dynamics. High spatial variability in solar radiation transmissivity is directly related to small-scale disturbances, which is a characteristic of old-growth forests in the absence of fires (Gauthier et al. 2010), as is the case for the study area for which no fires have been reported over the last 50 years. Moreover, the wide age range of saplings harvested in the advanced regeneration observed in $N$. dombeyi gaps varies between 12 and 40 years; saplings are visibly related to the formation and development of various size of gaps in response to small-scale disturbances.

EFFECTS OF SOLAR RADIATION TRANSMISSIVITY ON NATURAL REGENERATION DENSITY, RADIAL INCREASE AND PLANT HEIGHT The highest densities for advanced regeneration were observed in 13 plots from 64 total plots, with location at the edges or centres of stand gaps. However, sapling density showed low correlation with diffuse solar radiation transmissivity $\left(\mathrm{R}^{2}=0.26\right)$ (Fig. 4). Our results indicate until $30 \%$ of diffuse solar radiation transmissivity advanced sapling regeneration was highest (5 saplings $\mathrm{m}^{-2}$ ), and with low levels of diffuse solar radiation transmissivity, under $5 \%$, usually the density of advanced saplings was only 1 sapling $\mathrm{m}^{-2}$, with exception in one plot with 8 saplings $\mathrm{m}^{-2}$ (Fig. 4). These results coincide with a study by MüllerUsing (1973), who reported that for $N$. dombeyi regeneration density ranged from 0.08 to 0.8 plants $\mathrm{m}^{-2}$ with diffuse solar radiation transmissivity between 1.8 and $7 \%$. The range of spatial regeneration variability was associated with diffuse solar radiation transmissivity between 3 and $40 \%$, values which Collet \& Chenost (2006) also reported for European beech (Fagus sylvatica L.).

In addition, our results are consistent with Saldaña \& Lusk (2003), namely that available light explains most variation in advanced $N$. dombeyi regeneration density. Likewise, a controlled experiment found that the scarce regeneration of $N$. dombeyi under canopies of old-growth forests is at least partially attributable to higher light compensation points -but not shade- tolerant species. This is a typical characteristic of shade-intolerant species qualified as pioneers, such as $N$. dombeyi (Lusk \& Del Pozo 2002). In this sense, site resources, especially water and nutrients in the soil, could be relevant to explain the density of advanced regeneration (Stancioiu \& O'Hara 2006).

However, presence or absentia saplings under the canopy of old-growth forests are not only explained by the level of light at ground level, but also by different factors such as competition from herbaceous plants, bushes and overstory-trees as well as climatic extremes such as drought or frost (Pacala et al. 1994; Stancioiu \& O'Hara 2006). Moreover, solar radiation transmissivity had no influence on the height of seedlings and saplings under the canopy for the height class shorter than $0.5 \mathrm{~m}$ (Table 3 ). This result is consistent with Promis et al. (2010) findings for Nothofagus betuloides (Mirb.) Oerst. and could be explained with low-height seedlings and saplings, high dependency on other site resources, especially water and nutrients in the soil (Aussenac 2000; Stancioiu \& O'Hara 2006). Studies developed by Lusk (2004) and Ammer et al. (2008) found the same, indicating that size and age might affect plants' growth response to resource availability.

In contrast, both diffuse and global solar radiation transmissivity highly influenced height classes $1<1.5$ $\mathrm{m}$, possibly reflecting high competition for this resource, forcing saplings to invest more energy in height growth (Table 3) especially in old-growth forests where light is scarce. However, diffuse and global radiation considerably influence plants $>2 \mathrm{~m}$ (Table 3 ), due to competition for access to higher proportions of diffuse radiation under the 
canopy (Lieffers et al. 1999). Müller-Using and Schlegel (1981) found in a study controlling shade conditions that $N$. dombeyi height significantly increased with increasing light intensity. In the case of small gaps with a more or less closed cover, diffuse light total and daily carbon gain is linearly related to total daily PPFD. The proportion of total daily carbon gain during sunflecks ranged from 15 to $60 \%$ (Chazdon 1986; Peri et al. 2009), and consequently, may be important for the discovery of regeneration under shaded canopies in Nothofagus (Peri et al. 2009). Thus, direct light with higher energy levels, but lower occurrence during the day, stimulates photosynthetic processes leading to higher growth rates. In this respect, it has been reported that the effect of direct and global solar radiation transmissivity on height increment is relevant at levels above $20 \%$, as in the case of N. betuloides (Lusk 2004). However, in large gaps, direct and global solar radiation transmissivity, produces an excess of light inhibits growths, due to high energy contents and can lead to the inhibition of photosynthesis if unavailable for long periods of the day (Dengel et al. 2015). In fact, high light levels in gaps in the Andes may be the cause of severe photoinhibition of $N$. dombeyi saplings (Donoso et al. 2013).

The largest increases in AHG occurred in the 15 to 23\% range of direct and global solar radiation transmissivity (Figs. 6 and 7). Factors explaining AHG in the present study were also reported by Lusk (2004), Ammer et al. (2008), and Promis et al. (2010), who see transmissivity of direct and global solar radiation and age as a partial explanation of AHG $\left(\mathrm{R}^{2}=0.7\right.$; Figs. 6 and 7$)$ because saplings also respond to other available site resources for growth. Therefore, maximum increases in growth do not correlate with the highest light level. An explanation is that competition in the advanced regeneration of $N$. dombeyi excludes other species from the understory; it could therefore be argued that ARG is much more sensitive to intraspecific competition than growth in height (Ammer et al. 2005). The observed AHG patterns suggest that advanced regeneration species compete mainly for light, simultaneously reducing total increases in biomass but increasing biomass in the stem area in terms of height at the expense of radial growth (Ammer et al. 2005).

Diaci et al. (2008) showed the relative importance of both diffuse and direct radiation transmissivity for the successful regeneration of $F$. sylvatica under canopy openings with diffuse radiation, which coincides with the findings in this study (Table 1). However, height classes ARG and AHG showed no correlation with diffuse solar radiation transmissivity, likely a response to competition for density and greater access to diffuse radiation under the canopy by light-demanding species (Lieffers et al. 1999).When competing for light, height growth is of prime importance due to mechanical stress, and therefore ARG and AHG are regulated by the local environment (Vanninen \& Mäkelä 2000). In this study, the local microenvironment and site resources, such as water availability, were not analysed, but future studies should take these into account.

SiLVicultural IMPLiCATIONS

The studied stands correspond to mono-specific old-growth evergreen $N$. dombeyi forests. As no universal definition for old-growth forests exists (Wirth et al. 2009), for this study, using a broader and more pragmatic approach, Shorohova et al. (2011) definition proved most suitable. They define old-growth forests as naturally regenerated forests with low human impact and dominated by trees that approach the end of their biological life cycle. This phase is interesting because it opens room for human intervention, such as forest rehabilitation or the practice of close-to-nature silviculture.

For old-growth $N$. dombeyi forests, it has been hypothesised that in the absence of large-scale disturbances, late successional species tend to settle under the canopy and replace early successional species; therefore, regeneration of these species would depend on disturbance frequency (Veblen et al. 1996b). However, this hypothesis does not apply to old-growth forests in this study, because oldgrowth canopy layers of $N$. dombeyi have been primarily affected by small-scale disturbances such as rain and snow pressure, giving rise to differently sized gaps that stimulate natural regeneration in absence of bamboo species such as Chusquea culeou (Lusk 2001). Wind also causes a variety of gap sizes that depend directly on the intensity and duration of storms, site heterogeneity and stand conditions. In this form, overstory gaps vary so much that it is difficult to distinguish between a medium gap with a low proportion of fallen trees and a mosaic of small gaps.

The old-growth $N$. dombeyi stands of this study contained mainly two features. First, the presence of single layered stands, since canopies are fully closed and a geometric extension of canopies largely prevents solar radiation transmissivity, especially diffuse radiation in the understory, which affects natural regeneration. The second condition was observed in gaps created by small-scale disturbances and consisting of saplings competing for light, since the trees in the upper canopy still reduce light availability in the lower canopy (Oliver \& Larson 1996). Similar to the seedling and sapling regeneration of $N$. betuloides (Promis et al. 2010), regeneration in this study developed slowly in the understory, where saplings needed 20 to 40 years to reach a height of $5 \mathrm{~m}$, without forming a consistent secondary tree layer. From this perspective, it is necessary to recommend a silvicultural system that ensures natural regeneration in an old-growth $N$. dombeyi forest. Silvicultural systems consider multiple and often conflicting management objectives. Due to the high economic and ecologic value of the species presented here, it is necessary to preserve attributes of this forest type (Bauhus et al. 2009). Thus, the group selection method constitutes an appropriate method to promote regeneration, given that trees are removed in 
small groups (Lindenmayer \& Franklin 2002) and felling can continue at the border of the created gap. This method results in more or less "homogeneous" canopy gap patterns which allow for more resources, especially light, in areas lacking regeneration (Nyland 2002).

In the case of old-growth forests, no competition with $C$. culeou occurs and gaps are related to small areas on the forest floor where regeneration can develop over several years. However, the demand for light increases with age (Lieffers et al. 1999), making it necessary to expand existing gaps and create new ones to sustain the regeneration of new plants. These new gaps should imitate the collapse of old-growth trees, i.e. gaps should allow for enough light to stimulate regeneration; hence, cutting two to three trees of the overstory could prove useful, as it results in gaps with a diameter of around $30 \mathrm{~m}(0.07 \mathrm{ha})$, depending on stand density and tree size (Dezzotti \& Sbrancia 2006). However, it is necessary to adjust silvicultural practices, particularly the level of canopy openings, to maintain species composition unaffected as a key indicator of sustainability at management unit scale (Sola et al. 2015). Likewise, it is necessary to analyse the impact on biodiversity related to this silvicultural regime. The existing gaps are large enough to introduce other tree species complementing the natural regeneration of shade tolerant $N$. dombeyi, such as Laureliopsis philippiana and Podocarpus saligna (D. Don), and Nothofagus alpina, which protects against excess lighting in the gap (Dezzotti 2008). Regarding gap size, Dezzotti \& Sbrancia (2006) found an average $N$. dombeyi regeneration of 61.2 plants $\mathrm{m}^{-2}$ with observed gap sizes of 0.15 and 0.4 ha, demonstrating the effectiveness of this approach. These sizes suggest that gaps should have a maximum width of 40 to $60 \mathrm{~m}$ in wet temperate climates, preferably with winter rains. Under these weather conditions, gaps meet the objective of not creating central areas that are too large for the transmissivity of direct or global solar radiation or for natural regeneration defences against late frosts or desiccation (Dezzotti \& Sbrancia 2006).

In this study, the range of the solar radiation transmissivity spectrum was lower, than wet temperate climate zones, expressed in a maximum transmissivity value of $40 \%$. Therefore, gap sizes should be even smaller, in areas of Mediterranean climates, and this justifies that we propose a diameter of no more than $30 \mathrm{~m}$ for gaps and the study of enrichment techniques using shade-tolerant species.

\section{CONCLUSION}

In the case of old-growth $N$. dombeyi forest, recurrence of wind and snowstorms and the geometry of canopies cause the loss of individual trees if the storms are of low intensity. In cases of intense storms, the loss of a greater number of trees provides more and larger canopy openings. The age of higher plants varied between 12 and 40 years trying canopy opening at different times. It was estimated that the absolute radial increase of plants varied between 1.20 and $2.22 \mathrm{~mm}$ year $^{-1}$. However, the height classes, ARG and AHG did not correlate with the diffuse solar radiation transmissivity, but with the direct and global. Therefore, plant age and direct, and global transmittance of solar radiation through canopy openings explain the increases in diameter and height of saplings, and we recommend that local habitat and total sapling height of surrounding trees play a fundamental role in regulating competition in height growth for regeneration. Our findings suggest that single-tree or group-selection harvests should emulate the small-size gap disturbance as an important regeneration management for $N$. dombeyi oldgrowth forest.

\section{ACKNOWLEDGEMENTS}

The authors would like to thank the Chilean Project VRID 215.142.033-1.0 of the University of Concepción.

\section{REFERENCES}

Ammer, C., Stimm, B., Mosandl, R. 2008. Ontogenetic variation in the relative influence of light and belowground resources on European beech seedling growth. Tree Physiology 28: 721-728.

Ammer, C., Ziegler, C., Knoke, T. 2005. Zur Beurteilung von intraund interspezifischer Konkurrenz von Laubbaumbeständen im Dickungsstadium. Allgemeine Forst -und Jagdzeitung 176: 85-94.

Attiwill, P.M. 1994. The disturbance of forest ecosystems: the ecological basis for conservative management. Forest Ecology and Management 63: 247-300.

Aussenac, G. 2000. Interactions between forest stands and microclimate: Ecophysiological aspects and consequences for silviculture. Annals of Forest Science 57: 287-301.

Baldocchi, D., Collineau, S. 1994. The physical nature of solar radiation in heterogeneous canopies: spatial and temporal attributes. In: Caldwell, M.M., Pearcy, R.W. (ed.) Exploitation of environmental heterogeneity by plants; ecophysiological processes above and below ground. pp. 21-71. Academic Press, New York.

Bauhus, J., Puettmann, K., Messier, C. 2009. Silviculture for oldgrowth attributes. Forest Ecology and Management 258: 525-537.

Canham, C.D., Coates, K.D., Bartemucci, P., Quaglia, S. 1999. Measurement and modeling of spatially explicit variation in light transmission through interior cedar-hemlock forests of British Columbia. Canadian Journal of Forest Research 29: 1775-1783.

Canham, C.D., Finzi, A.C., Pacala, S.W., Burbank, D.H. 1994. Causes and consequences of resource heterogeneity in forests: interspecific variation in light transmission by canopy trees. Canadian Journal of Forest Research 24: 337-349. 
Canham, C.D., Denslow, J.S., Platt, W.J., Runkle, J.R., Spies, T.A., White, P.S. 1990. Light regimes beneath closed canopies and tree-fall gaps in temperate and tropical forests. Canadian Journal of Forest Research 20: 620-631.

Collet, C., Chenost, C. 2006. Using competition and light estimates to predict diameter and height growth of naturally regenerated beech seedlings growing under changing canopy conditions. Forestry 79: 489-502.

Chazdon, R.L. 1986. Light Variation and Carbon Gain in Rain Forest Understorey Palms. Journal of Ecology 74: 9951012.

Chazdon, R.L., Pearcy, R. 1986. Photosynthetic responses to light variation in rainforest species. I. Induction under constant and fluctuating light conditions. Oecologia 69: 517-523.

Del Pozo, A., Del Canto, P. 1999. Áreas agroclimáticas y sistemas productivos en la VII y VIII Región. Instituto de Investigaciones Agropecuarias CRI Quilamapu. Serie Quilamapu N 113.115 pp.

Dengel, S., Grace, J., MacArthur, A. 2015. Transmissivity of solar radiation within a Picea sitchensis stand under various sky conditions. Biogeosciences 12: 4195-4207.

Dezzotti, A. 2008. Acumulación y asignación de biomasa en renovales de tres especies de Nothofagus en los extremos de un gradiente de luz en claros de un bosque subantártico. Investigación Agraria: Sistemas y Recursos Forestales 17: 18-30.

Dezzotti, A., Sbrancia, R. 2006. Patrón espacial de la regeneración de un rodal mixto de Nothofagus en claros. Revista de la Facultad de Agronomía 106: 85-96.

Diaci, J., Gyoerek, N., Gliha, J., Nagel, T.A. 2008. Response of Quercus robur $l$. seedlings to north-south asymmetry of light within gaps in floodplain forests of Slovenia. Annals of Forest Science. 65: 1-8.

Donoso, P.J., Lusk, C.H. 2007. Differential effects of emergent Nothofagus dombeyi on growth and basal area of canopy species in an old-growth temperate rainforest. Journal of Vegetation Science 18: 675-684.

Donoso, P.J., Soto, D.P., Coopman, R.E., Rodriguez-Bertos. S. 2013. Early performance of planted Nothofagus dombeyi and Nothofagus alpina in response to light availability and gap size in a high-graded forest in the south-central Andes of Chile. Bosque 34: 23-32.

Gauthier, S., Boucher, D., Morissette, J., De Grandpré, L. 2010. Fifty-seven years of composition change in the eastern boreal forest of Canada. Journal of Vegetation Science 21: 772-785.

GonzÁlez, M.E., Donoso, P.J., Szejner, P. 2015. Tree-fall gaps and patterns of tree recruitment and growth in Andean oldgrowth forests in south-central Chile. Bosque 36: 383-394.

Hardy, J.P., Melloh, R., Koenig, G., Marks, D., Winstral, A., Pomeroy, J.W., Link, T. 2004. Solar radiation transmission through conifer canopies. Agricultural and Forest Meteorology 126: 257-270.

Hu, L., ZHu, J. 2008. Improving gap light index (GLI) to quickly calculate gap coordinates. Canadian Journal of Forest Research 38: 2337-2347.

Kneeshaw, D.D., Bergeron, Y. 1998. Canopy gap characteristics and tree replacement in the southeastern boreal forest. Ecology 79: 783-794.

Kühne, A., Villarroel, A., Peña, I. 2005. Estudio agrológico del área de Yungay y Ninhue, VIII Región. Ministerio de Agricultura, Servicio Agrícola y Ganadero, División de Protección de los Recursos Naturales Renovables. 120 p.

LAPIN, M. 2005. Old-Growth Forests: A literature review of the characteristics of eastern North American forests. Vermont Natural Resources Council, Montpelier, Vt. 22 pp.

Leuchner, M., Hertel, C., Rötzer, T., Seifert, T., Weigt, R., Werner, H., Menzel, A. 2012. Solar radiation as a driver for growth and competition in forest stands. In: Matyssek, R, Schnyder, H, Oßwald, W, Ernst, D, Munch, JC, Pretzsch, H (eds.) Growth and Defence in Plants: Resource Allocation at Multiple Scales. Pp: 175-191. Ecological Studies vol. 220.

Lieffers, V.J., Messier, C., Stadt, K.J., Gendron, F., Comeau, P.G. 1999. Predicting and managing light in the understory of boreal forests. Canadian Journal of Forest Research 29: 796-811.

Lindenmayer, D.B., Franklin, J.F. 2002. Conserving forest biodiversity. A comprehensive multiscaled approach. Island Press, Washington DC. 352 pp.

Long, S.P., Humphries, S., Falkowski, P.G. 1994. Photoinhibition of photosynthesis in nature. Annual Review of Plant Physiology and Plant Molecular Biology 45: 633-662.

Luebert, F., Pliscoff, P. 2006. Sinopsis bioclimática y vegetacional de Chile. Editorial Universitaria. Santiago, Chile. 316 pp.

Lusk, C.H. 2001. Cuando un claro no es un claro?: Niveles lumínicos e índice de área foliar en claros ocupados por Chusquea quila, en un bosque lluvioso chileno. Gayana Botanica 58: 25-30. URL: http://dx.doi.org/10.4067/ S0717-66432001000100003.

Lusk, C.H. 2004. Leaf area and growth of juvenile temperate evergreens in low light: species of contrasting shade tolerance change rank during ontogeny. Functional Ecology 18: 820-828.

Lusk, C.H., Del Pozo, A 2002. Survival and growth of seedlings of 12 Chilean rainforest trees in two light environments: Gas exchange and biomass distribution correlates. Austral Ecology 27:173-182.

Martens, S.N., Breshears, D.D., Meyer, C.W. 2000. Spatial distributions of understory light along the grassland/forest continuum: effects of cover, height, and spatial pattern of tree canopies. Ecological Modelling 126: 79-93.

Mitchell, S.J. 2013. Wind as a natural disturbance agent in forests: a synthesis. Forestry 86: 147-157.

Mountford, E.P., Savill, P.S., BebBer, D.P. 2006. Patterns of regeneration and ground vegetation associated with canopy gaps in a managed beech wood in southern England. Forestry 79: 389-408.

Müller-Using, B. 1973. Untersuchungen über die Verjüngung von Nothofagus alpina (Poepp. et Endl) Oerst. und ihrer wichtigsten Begleitbaumarten in der chilenischen anden und Küsten-Kordillere. Inaugura. Dissertation, Universität zu München. Deutschland. 289 pp.

Müller-Using, B., Schlegel, F. 1981. The development of seedlings of Chilean Nothofagus species in a shaded area. Plant Research and Development 12: 152-184.

Nyland, R.D. 2002. Silviculture. Concepts and applications. Waveland Press, Inc., Illinois. $682 \mathrm{pp}$.

Oliver, C.D., Larson, B.C. 1996. Forest stand dynamics. Update Edition. John Wiley and Sons, Inc., New York. 520 pp. 
Pacala, S.W., Canham, C.D., Silander, J.A., Kobe, R.K. 1994. Sapling growth as a function of resources in a north temperate forest. Canadian Journal of Forest Research 24: 2172-2183.

Parhizkar, P., Sagheb-Talebi, K., Mataji, A., Nyland, R., NAmiranian, M. 2011. Silvicultural characteristics of Oriental beech (Fagus orientalis Lipsky) regeneration under different RLI and positions within gaps. Forestry 84: 177-185.

Parker, G.G., Davis, M.M., Chapotin, S.M. 2002. Canopy light transmittance in Douglas-fir-western hemlock stands. Tree Physiology 22: 147-157.

Peri, P.L., Martínez-Pastur, G., Lencinas, M.V. 2009. Photosynthetic response to different light intensities and water status of two main Nothofagus species of southern Patagonian forest, Argentina. Journal of Forest Science 55: 101-111.

Promis, A., Gärtner, S., Reif, A., Cruz, G. 2010. Effects of natural small-scale disturbances on below-canopy solar radiation and regeneration patterns in an old-growth Nothofagus betuloides forest in Tierra del Fuego, Chile. Allgemeine Forst -und Jagdzeitung 181: 53-64.

Rijkers, T., Jan de Vries, P., Pons, T.L., Bongers, F. 2000. Photosynthetic induction in saplings of three shade-tolerant tree species: comparing understorey and gap habitats in a French Guiana rain forest. Oecologia 125: 331-340.

SAldaña, A., Lusk, C.H. 2003. Influencia de las especies del dosel en la disponibilidad de recursos y regeneración avanzada en un bosque templado lluvioso del sur de Chile. Revista Chilena de Historia Natural 76: 639-650.

Schlegel, B.C., Donoso, P.J. 2008. Effects of forest type and stand structure on coarse woody debris in old-growth rainforests in the Valdivian Andes, south-central Chile. Forest Ecology and Management 255: 1906-1914.

Shorohova, E., Kneeshaw, D., Kuuluvainen, T., Gauthier, S. 2011. Variability and dynamics of old-growth forests in the circumboreal zone: implications for conservation, restoration and management. Silva Fennica 45: 785-806.

Sola, G., Beltrán, H.A., Chauchard, L., Gallo, L. 2015. Efecto del manejo silvicultural sobre la regeneración de un bosque de Nothofagus dombeyi, N. alpina y N. obliqua en la Reserva Nacional Lanín (Argentina). Bosque 36: 113120.

Sola, G., El Mujtar, V., Tsudad, Y., Vendramin, G.G., Gallo, L. 2016. The effect of silvicultural management on the genetic diversity of a mixed Nothofagus forest in Lanín Natural Reserve, Argentina. Forest Ecology and Management 363: 11-20.

Stanciolu, P.T., O'Hara, K.L. 2006. Regeneration growth in different light environments of mixed species, multiaged, mountainous forests of Romania. European Journal of Forest Research 125: 151-162.

Valladares, F., Guzmán, B. 2006. Canopy structure and spatial heterogeneity of understory light in an abandoned Holm oak woodland. Annals of Forest Science 63: 49-761.

Valladares F., NiINEMETS, Ü. 2008. Shade tolerance, a key plant feature of complex nature and consequences. Annual Review of Ecology, Evolution, and Systematics 39: 23757.

VAnNinen, P., MäKelä, A. 2000. Needle and stem wood production in Scots pine (Pinus sylvestris) trees of different age, size and competitive status. Tree Physiology 20: 527-533.

Veblen, T.T., Kitzberger, T., Burns, B.R., Rebertus, A.J. 1996a. Perturbaciones y dinámica de regeneración en bosques andinos del sur de Chile y Argentina. En: Armesto, J.J., Villagrán, C., Arroyo, M.T.K. (eds.), Ecología de los bosques nativos de Chile, pp. 169-198. Editorial Universitaria, Santiago, Chile.

Veblen, T.T., Donoso, C., Kitzberger, T., Rebertus, A.J. 1996 b. Ecology of southern Chilean and Argentinean Nothofagus forests. In: Veblen, T.T., Hill, R.S., Read, J. (eds.), The ecology and biogeography of Nothofagus forests, pp. 293353. Yale University Press, New Haven, USA.

VyNCKE, G. 1969. Étude du rapport entre l'éclairement relatif sous forêt et l'éclairement lumineux incident en phénophase feuillée. Sylva Gandavensis 16: 1-15.

Wirth, K., Messier, C., Bergeron, Y., Frank, D., Fankhänel, A. 2009. Old-growth forest definitions: a pragmatic view. In: Wirth, K. et al. (eds.), Old-growth forests. Ecological Studies, Vol. 207, pp. 11-33. Springer-Verlag, BerlinHeidelberg, Germany.

Recibido: 14.06 .2018

Aceptado: 26.09.2018 